\title{
ВИНОГРАДОВ В.Б.: О НАУЧНОЙ ДЕЯТЕЛЬНОСТИ; О ЧЕЧЕНСКОМ ТАЙПОВОМ ОБЩЕСТВЕ ТУМСОЙ
}

\author{
Дахо Алви Ахмедгириевич \\ Комплексный научно-исследовательский институт им. Х.И. Ибрагимова РАН, \\ 2. Грозный \\ Соискатель ученой степени кандидата исторических наук \\ Дахо Джохар Алвиевич \\ Чеченский государственный университет им. А.А. Кадырова, \\ 2. Грозный \\ Магистр
}

\begin{abstract}
Аннотация. В данной работе мы намерены представить краткие сведения о личности и научной деятельности В.Б. Виноградова, под углом их критического осмысления. Также мы намерены представить и полный текст статьи «У подножия горы тумсойцев», опубликованной автором в книге под названием «Через хребты веков», вышедшей в свет в 1970 году, сопровождая её своими комментариями относительно некоторых моментов, требующих, на наш взгляд, дополнительных пояснений.

Abstract. In this paper, we intend to present brief information about the personality and scientific activities of V.B. Vinogradov, from the angle of their critical reflection. We also intend to present the full text of the article "At the foot of the mountain of Tumsoy", published by the author in a book called "Through the ridges of centuries", published in 1970, accompanying it with our comments on some points that, in our opinion, require additional explanations.

Ключевые слова: Аргунское ущелье, Тумсой, Тумсой-Лам, башни Тумсоя, Тумцойцев кабак, Ватан-Корта.

Keywords: Argun gorge, Tumsoy, Tumsoy-Lam, Tumsoy towers, Tumtsoytsev tavern, Vatan-Korta.
\end{abstract}

Виноградов Виталий Борисович посвятил научной деятельности более пятидесяти лет своей жизни. Из них более тридцати лет он работал в Чечено-Ингушетии. Его творческое наследие до сих востребовано в научном мире и, вместе с тем, вызывает разносторонние оценки со стороны как последователей его «Школы», так и многочисленных его оппонентов и критиков. В данной статье, посредством небольшого экскурса в дискурсивное поле намеченной темы, мы ставим задачу сделать собственный вывод относительно значимости и практической востребованности трудов Виноградова В.Б. в современной науке, в частности в чеченском научном сообществе.

Краткие сведения о научной деятельности: Виноградов В.Б. - кавказовед, Заслуженный деятель науки Чечено-Ингушской АССР (1978), Заслуженный деятель науки РСФСР (1982), Заслуженный деятель науки Кубани, член Союза журналистов России. Также - академик научной школы Международной академии наук, академик Международной академии информатизации, академик Общественной академии наук, культуры, и образования Кавказа. Он родился в г. Грозный в апреле 1938 года. Умер в сентябре 2012 г. После завершения учебы на историческом факультете МГУ им. М.В. Ломоносова (1961 г., г. Москва) он возвращается в Грозный. Его принимают на работу в Чечено-Ингушский научно-исследовательский институт истории, языка и литературы. В 1963 году под его авторством вышла в свет монография с названием «Сарматы СевероВосточного Кавказа». В 1964 г. Виноградов В.Б. защитил диссертацию по отечественной истории и получил ученую степень кандидата наук. В 1973 году защитил докторскую диссертацию по теме «Центральный и Северо-Восточный Кавказ в скифское время». С того же 1973 г. по 1992 г. работал в Чечено-ингушском государственном университете (ЧИГУ) им. Л.Н. Толстого в качестве профессора кафедры всеобщей истории. «Трагические события начала 1990-х вынудили В.Б. Виноградова вместе с семьей и рядом учеников покинуть Чеченскую республику».[1, с. 110] Далее он продолжил свою научную деятельность в Армавирском государственном педагогическом институте в качестве профессора кафедры отечественной истории.

Х.Д. Ошаев в одной из своих статей отмечал следующее о научно-творческой деятельности В.Б. Виноградова в начале 70-х гг. ХХ в.: «В журнале Академии Наук СССР «Советская этнография», в третьем номере за май-июнь 1972 года В.Б. Виноградовым опубликована статья под заглавием «О месте первоначального расселения гребенских казаков».

В последние два-три года Чечено-Ингушское книжное издательство дает Виноградову неограниченную возможность для издания его скороспелых, в большей мере лженаучных творений. Чувствуя здесь, в ЧеченоИнгушетии, полную бесконтрольность, он, как блины, печет никем не проверенные, неотрецензированные опусы, в которых, не моргнув глазом, извращает исторические факты, либо представляет в них желаемое как действительность. 
В последнее время он смог добиться печатания своих творений и на страницах солидных московских журналов, как, например, «Советская этнография».[2, с. 60]

В 1982-1987 гг. Виноградов В.Б. занимал должность заведующего кафедры всеобщей истории ЧИГУ им. Л.Н. Толстого. В 1987 году он назначается заведующим вновь созданной межвузовской кафедры истории народов Северного Кавказа.

В памяти чеченской общественности Виноградов В.Б. запомнился в качестве основного «разработчика» (автора) «Концепции добровольного вхождения Чечено-Ингушетии в состав России», выдвинутой в научноидеологическое пространство ЧИАССР в 1970-х гг.. «Концепция» признавала понятие «Кавказская война» лишь условно, лишая его фактической содержательности. Правильными и научно-обоснованными признавались «ею» только понятия «интеграция», «формирование государственного единства», «притирание» и «органическое совмещение» Российской империи и горских обществ. Так, Дударев С.Л. (один из учеников В.Б. Виноградова примеч. наше - Дахо А.A.) отмечает: «Особое место в судьбе ученого занимала тема русско-северокавказских взаимоотношений, формирования государственного единства народов Северного Кавказа и России. Он выступил одним из основных разработчиков концепции «добровольного вхождения Чечено-Ингушетии в состав России, неоднозначно воспринятой частью кавказоведов».[1, с. 110] Заказчиком и главным проводником такой «концепции», конечно же, выступало тогдашнее политическое руководство Чечено-Ингушетии. «Виноградовщина» - вот такое в те годы неофициальное название получила вся эта пропагандистская кампания в народе.

В работе А.А. Журтовой и А.Н. Максимчик пишется: «В процессе изучения поставленной проблемы ученые и публицисты дают различные оценки взаимоотношений народов Центрального Кавказа с Российской империей. Концептуальные различия «завязаны» вокруг следующих понятий: «подданство», «добровольное присоединение», «вхождение», «военно-политический союз», «российскость» и др., при этом у разных авторов одна и та же категория наполнена различным семантическим содержанием. Одна часть ученых в качестве главного фактора имперской политики в регионе рассматривает стремление к территориальным приращениям, предполагающим жесткое подавление любых форм сопротивления со стороны завоеванных народов. Другая сосредотачивается на обосновании того, что Российская империя по своему государственно-территориальному устройству представляла собой идеальный вариант организации власти и управления национальными окраинами, способствовавший благотворному влиянию русского народа на материальную и духовную культуру северокавказских этнических обществ. Все это создает сложную палитру мнений и оценок, которые политизируются, идеологически конфликтуют и создают дискурсивное поле, требующее глубокого научного исследования».[3, с. 16] Относительного понятия «российскость», имеющего место в приведенном выше отрывке из работы Журтовой и А.Н. Максимчик, Дударев С.Л. пишет следующее: «Постигая историю региона, ученый (В.Б. Виноградов - примеч. наше - Дахо А.А., Дахо Д.А.), всегда акцентировал внимание на многовековом позитивном опыте добрососедства и взаимовыгодного общения коренных этносов Кавказа и России, в результате чего в 1993 г. в научный оборот им была введена актуальная концепция «Российскости». Эта новаторская дефиниция, нашедшая сегодня весьма широкое признание, выражает длительную тенденцию органичного сближения народов в составе Российского государства».[1, с. 111]

В.Б. Виноградов является автором большого числа научных, научно-популярных изданий. К его основным сочинениям относят: «Сарматы Северо-Восточного Кавказа.-Грозный,1963.—224c.; Чечено-Ингушетия в советской исторической литературе. Крити-ко-библиографический обзор. - Грозный.- 82с.(в соавт.); Археологические памятники Чечено-Ингушской АССР (материалы к археологической карте) - Грозный,1966. -165с.(в соавт.); Тайны минувших времен. - М.: Наука, 1966. - 167 с.; Через хребты веков. - Грозный: Чечено-Ингушское книжное издательство, 1970. —166 с.; О памяти, о подвигах, о славе! — Грозный, 1972.—88 с.(в соавт.); Центральный и Северо-Восточный Кавказ в скифское время (VII-IVвв. до н. э.).- Грозный, 1972. —391 c.; Möödunu tummad tunistajad. Vene fceelest tolkinud Hans Aasmaa. — Tallinn: Valgus, 1973. —155 c. (на эстонск. яз.); Время, горы, люди. Книга очерков и краеведческих репортажей. - Грозный: Чечено-Ингушское книжное издательство, 1980. - 168 с.; Навеки вместе. - Грозный, 1980. -120 с. (в соавт.); Религиозные верования в дореволюционной Чечено-Ингушетии.-Грозный, 1981. - 111 с.(в соавт.); Судьбы древних монет. - Грозный, 1982, 95 с.,24 с., илл.; Памяти вечная нить. - Грозный, 1988. — 135 с.; Народной памяти следы (Краткиеи сторико-культурные очерки о районах Чечено-Ингушской АССР). - Грозный, 1989. — 56 с.; Очерки этнографии чеченцев и ингушей. - Грозный, 1990. — 96 с. (в соавт.); Старинные монеты - свидетели прошлого. - Нальчик, 1990. - 80 с.(в соавт.); Топонимия Средней Кубани. - Армавир, 1993. - 80 с.; Основные этапы всемирной истории. Методический материал в помощь изучающим всеобщую историю (для обсуждения). - Армавир, 1993. - 20 с.(в соавт.); Средняя Кубань: земляки и соседи (формирование традиционного состава населения). Книга историко-культурных регионоведческих очерков. - Армавир, 1995. - 150 с.; Кавказ в передовой общественно-политической мысли России (вторая половина XVIII - первая треть XIX в.). Полемические этюды. - Армавир, 1996. 62 с. (в соавт.); «Уголок России, отчий дом...» Очерки истории Тарумовских степей и Кизлярщины. - Армавир-Кизляр, 1996. —54 с.; Из истории и культуры Кубани: 30 рецензий. - Армавир, 1997. —120 с.; На терских берегах. Очерки об исторических группах старожильческого 
населения Среднего Притеречья. - Армавир, 1997. -64 с.(в соавт.); Пушкинская Кубань (историколитературоведческие этюды). - Армавир, 1999. - 72 с.; Генерал Г.Х. Засс: «Отступления со мною нет и не будет!»/Лики Российской истории Северного Кавказа. Вып.1. -Армавир, 2000. - 20 с.; Ханкальские древности — источник по истории и культуре местных племен I тыс. дон. э. — I тыс .н. э. — Армавир, 1999. — 52 с. (в соавт.); Россия и Северный Кавказ: история в зеркале художественной литературы (сборник статей). -Армавир, 2003. - 120 с.; Кабардинцы и вайнахи на берегах Сунжи (XVI - середина XVIII в.). - Aрмавир \$ Майкоп,2003. - 154 с. (в соавт.); Российский Северный Кавказ: факты, события, люди (книга регионоведческих статей, очерков и зарисовок). - М.; Армавир, 2006. - 160 с.; Мои журналистские и общественные университеты. - М.; Армавир, 2006. - 56 с.; Современные аспекты российского кавказоведения (Мозаика новейших публикаций). - М.; Армавир, 2007. - 60 с.; Из эпизодов «лермонтовского Кавказа». Под ред. В. А.Захарова. - М.; Армавир, 2007. -56 с. (в соавт.); Сборник избранных статей Виталия Борисовича Виноградова (к70-летию со дня рождения). -Армавир, 2008. - 228 с.; А.А. Бестужев (Марлинский): историкоэтнографические реалии повести «Аммалат-бек». Практические опыты исторического регионоведения. Вып. 53. -М.; Армавир, 2009. - 60 с. (в соавт.); А.А. Бестужев (Марлинский): историко-этнографические реалии повести «Аммалат-бек». Практические опыты исторического регионоведения (Ч.ІІ). Вып. 54. — М.; Армавир, 2009. 77 с. (в соавт.); Российская власть и горский традиционный уклад: очерки взаимодействия в конце XVIII начале XXI века. - Славянск-на-Кубани, 2012. - 224 с. (в соавт.)».[4, с. 14-15] По имеющимся данным, под авторством Виноградова В.Б. было издано более 1350 научных, научно-популярных и научно-методических работ, в том числе и в зарубежных изданиях.

В статье Ислама Баудинова под названием «В.Б. Виноградов, кавказоведческая Школа академика В.Б. Виноградова, история народов Северного Кавказа» пишется: «В связи с негативной публичной деятельностью проводимой т.н. «кавказоведческой Школой В.Б. Виноградова» (г. Армавир Краснодарского края), а также попытками монополизации истории народов Северного Кавказа в руках узкого круга «школьников» для профессиональных историков определилась необходимость осмысления ситуации в целях преодоления реальной опасности общественно-политической конфронтации».[5] В продолжение данной темы, И. Баудинов, далее - в той же работе, по пунктам перечисляет «тезисы» научного видения этой «Школы», представляющие, на взгляд автора, общественно-политическую опасность (стилистика и орфография соответствует оригиналу

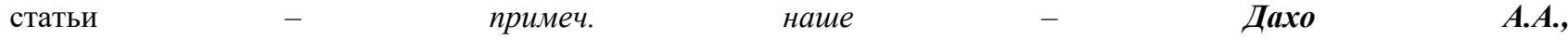
Дахо Д.А.):

«- горские народы являются не субъектом исторического процесса, а его объектом, «элементами» в процессе «интегрирующей роли русской государственной и цивилизационно-культурной составляющей»;

- все факты репрессивной политики русских властей в отношении «немирных обществ» (Северного Кавказа. - И.Б.) почти не выходят за рамки фрагментарно отслеживаемых происшествий». Не было ни Кавказской войны, ни национально-освободительного движения с громадными жертвами, а была справедливая борьба интегрирующего «центра» против «набеговой экспансии» горцев Дагестана, Чечни и Черкесии с приведением их к имперскому порядку;

- «геноцида адыгов» так же не было. Все разговоры о жестоком изгнании царизмом черкесов (адыгов) Северо-Западного Кавказа в Османскую империю от лукавого. В крайнем случае, была добровольная «миграция» адыгов за границу т.к. вследствии своей порочной ментальности они не могли ужиться в условиях благотворных законов Российской империи;

- любые попытки изучения национально-освободительных движений в северокавказских республиках с иных позиций кроме как определенных В.Б. Виноградовым и его командой являются поползновением «расшатать государственно-цивилизационное единство нашей Родины, порожденное фактором «российскости»;

- чеченцы, ингуши и, по всей видимости, адыги (в первую очередь кабардинцы) не являются первопоселенцами на равнинах Северного Кавказа. Те же чеченцы, захватили «русские» земли по Сунже и Тереку только в XVШ в. Ранее кабардинцев и чеченцев их освоили некие «восточнославянские элементы» и «рязанские казаки», сложившиеся в XV1-XVП вв. в Терско-Гребенское казачье войско. Россия в X1X в. вела на Тереке и Кубани «отвоевание» исконно русских земель (тезис о «русских равнинах» и «вайнахских горах» стал расхожим и в ряде откровенно фашистских сайтов Интернета);

- деятельность указанной «Школы» и «принципиальная позиция» ее коллектива внесли «свою лепту» в преодоление «кризисной ситуации несущей в себе страшный заряд гибельный для архитектоники всего евразийского пространства (Это не шутка, это цитата! - И.Б.)»;

- ученые осмелившиеся оспорить взгляды отдельных виноградовцев и «Школы» в целом, занимаются «бесчестной критикой», высказывают «голословные» реплики, совершают «нападки» и попросту ангажированны (в отличие от армавирских носителей истины) «идеями разрушения единой истории нашего общего Отечества». Причем в этом ряду находятся не только горские, но и русские историки, не преклонившиеся перед величием «парадигмы российскости»;

- носителем истины в последней инстанции, неутомимым организатором сопротивления попыткам национальных историков сказать свое слово, создателем «кавказоведческой Школы академика В.Б. 
Виноградова», автором концепции «российскости», «мудрым учителем и наставником», «Патриархом», «Учителем», «Шефом» и «Человеком» с большой буквы, является на сегодня именно В.Б. Виноградов. Соответственно его ученики именуются более скромно - «маститые» и «талантливые». ...»[5]

О моём (автор - Дахо А.A.) отношении к научному наследию Виноградова В.Б.: Мне довелось слушать лекции, участвовать в практических занятиях, сдавать зачёты и экзамены Виноградову В.Б. во второй половине 1980-х гг., будучи студентом исторического факультета ЧИГУ им. Л.Н. Толстого (г. Грозный). Профессор Виноградов В.Б. вел у нас занятия по археологии и этнографии. Запомнился он мне, многим моим сокурсникам и другим студентам-историкам своим высоким лекторским талантом, умением просто и доходчиво разъяснять довольно сложные вопросы и темы обучения, увлечь студента в мир прошлого, в тайны предмета познания и исследования в названных дисциплинах исторической науки. Он запомнился нам и как неподражаемый рассказчик различных легенд о нашей истории, владеющий большим объемом информации об истории различных чеченских тайповых сообществ. В работе со студентами, научный материал он умело «разбавлял» смешными рассказами-историями и занимательными анекдотами. Всё это вместе взятое притягивало к нему и давало нам возможность для открытого контакта и обсуждения с ним многих вопросов, переходивших иной раз в дружескую дискуссию. Конечно, к научному наследию ученого сложно подходить однозначно. Что больше в его трудах - правды, лжи, политической ангажированности, научной объективности и пр.? Это слишком сложный вопрос, требующий глубокого изучения всех его трудов и научного наследия, учитывая мнения и оценки многих исследователей, кто специально занимался этой проблемой. Тем не менее, со своей стороны, не могу не согласиться со справедливостью критики его «Концепции о добровольном вхождении чеченцев и ингушей в состав России», в частности и теми кавказоведами, которых подразумевал в своей статье Дударев С.Л.[1, с. 110] Более того, не считаю лишённой логики и основательности многих аспектов, изложенных в критике И. Баудинова относительно деятельности «Школы Виноградова В.Б.»[5] и других оппонентов Виноградова В.Б. относительно его научных взглядов и видения исторического прошлого чеченцев и ингушей, в которых превалировала точка зрения, исподволь или открыто подвергавшая сомнению историю чеченцев на Кавказе глубже средневековой эпохи. Есть у нас также немало свидетельств и о сомнительной «судьбе» множества ценнейших артефактов, обнаруженных в ходе археологических раскопок под руководством Виноградова В.Б., в т.ч. и находок из драгоценного металла, на различных культурно-исторических объектах ЧИАССР.

Между тем в трудах Виноградова В.Б., в значительной части, всё-таки отражается и правда о прошлом, в полной мере отвечающая подлинности и научной объективности. И эта «часть», по моим убеждениям, определённо перевешивает научно несостоятельную «часть» в его трудах. Нет сомнения в том, что многие спорные научные вопросы теряют свою актуальность с истечением какого-то отрезка времени, развитием знаний и результатов новых исследовательских разработок и открытий по данным проблемам. А правда и подлинные факты всегда остаются и утверждаются в исторической науке, служат основой для дальнейшего изучения различных тем и продвижения научной мысли вперед в будущем.

В этом плане нужно отметить следующее. Благодаря научным трудам Виноградова В.Б., соглашаться с выводами ученого или нет - это совсем другой вопрос, многие исследователи, в том числе и мы, имеют обширный фактический материал для работы, по сути, являющийся ценным арсеналом источников и разносторонней информации. К примеру, в книге «Время, горы, люди» дается материал о научных изыскания (в т.ч.) в Аргунском ущелье (гл.: «Сокровище Аргунского ущелья»).[6, с.36-43] В работе «О памяти, о подвигах, о славе!» авторы (Виноградов В.Б. и В. Байбик), основываясь на солидном этнографическом материале, пишут о гибели «Алхан-Калинского городища на реке Сунже».[7, с. 17-18] Об этих же событиях пишется и в главе «Город на берегу Сунжи» книги «Тайны минувших времен».[7, с. 17 -26] Примечательное место в сочинениях автора занимает изложение сведений о раскопке Сержень-Юртовского холма (книга «Тайна минувших времен»). Данное описание может характеризоваться одним из наиболее ярких примеров, когда профессиональный археолог-исследователь, основываясь на конкретном материале, производит мастерскую реконструкцию событий далёкого исторического прошлого.[8, с. 12-17] Таких работ, заслуживающих внимания исследователей, в перечне трудов у автора в большом количестве. Мы перечислили из них лишь некоторые.

В ряде научных работ мы и сами опирались на различные труды Виноградова В.Б. К примеру, в статье «Март-нах: кто они?»[9, с. 67, 68] Также в статьях «Нахча-Корта: по следам минувших столетий (результаты первого этапа историко-этнографической экспедиции)»[10] и «К вопросу изучения Ачхоевско-Бамутской горнолесистой зоны Чеченской Республики (по материалам историко-этнографической экспедиции)».[11]

В данной статье мы также намерены представить текст ещё одного очерка-рассказа Виноградова В.Б., включенного автором в книгу «Через хребты веков»[13] под названием «У подножия горы тумсойцев», сопровождая его некоторыми своими примечаниями и комментариями. Этот очерк-рассказ для нас интересен и тем, что в нем, в частности, излагаются интересные сведения о чеченском тайповом обществе Тумсой, дающие нам дополнительный историко-этнографический материал, который мы намерены в дальнейшем использовать в работе над монографией «Тумсой из народа Нохчий», проводимой нами в настоящее время под руководством д. и. н., профессора Гарсаева Л.М. 
Далее приводим текст самого очерка-рассказа, полностью сохраняя орфографию и стилистику автора: «Горная Чечено-Ингушетия... Дивный и величественный край. Седые вершины гор и соперничающие с ним в белизне стремительные водопады, своенравные реки и подернутые дымкой туманов суровые ущелья. Сколько чудесного видели они, сколько вековых тайн скрывается здесь!

Вот на невероятной высоте прилепилась к скале серая башня. О ней из поколения в поколение передаются легенды, и нет им числа. Тропинка огибает небольшой погребальный домик-склеп, последнее пристанище безвестного вайнахского рода. Многое могли бы рассказать его сизые от мха стены. А там - вдали - развалины древнего святилища. Крыша его обвалилась, вокруг запустение, тишина. А ведь когда-то тут кипела жизнь и, перемешиваясь с жертвенным дымом, в небо уносились молитвы, просьбы, заклинания. Люди верили в чудеса, в сверхъестественные силы и безропотно приносили к храму то, что было нажито их трудом, их потом, немыслимым напряжением мозолистых рук.

Горы рождают людей храбрых и сильных, людей мужественных и упорных. Их прошлое - это тяжкий труд, яростная борьба за лучшую долю и безмерная, сыновняя любовь к своей Родине. Так было всегда, и история бережно хранит память о многих поколениях вайнахов, для которых верховья правых притоков буйного Терека - святая земля их предков.

Чей это бешеный гул

Слышится из далека?

Это несется Аргун -

Горная наша река.

Я не видел никогда

Столь необузданных вод, -

Будто упала звезда

В пенистый водоворот...

Таким увидел Аргун один из старейших чеченских поэтов Магомед Мамакаев. Такой он и есть неистовый, своевольный поток.

Полное красот природы Аргунское ущелье, где, по преданиям, сложились старинные чеченские родовые группы, в историко-археологическом отношении все еще остается «землей незнаемой». Правда, несколько довоенных разведок, а также полевые исследования В.И. Марковина в 1957 - 1962 годах выявили здесь немалое число уникальных и самобытных памятников древности. Грозные боевые башни и замки, усыпальницы-склепы, называемые в народе «маьлх-каш» (солнечные могилы), многочисленные древние кладбища и поселения дальних предков современных чеченцев - все это стало предметом научного изучения. Осторожные и заботливые руки археологов очистили от вековой пыли памятники материальной культуры, а пытливый ум ученых проникает ныне в самые сокровенные тайны, которые хранят до поры немые свидетели истории гор.

все-таки исследования специалистов пока охватили в основном лишь наиболее доступные, можно сказать, «придорожные» объекты. Несколько километров в сторону от дорог, вьющихся по дну ущелья, несколько сот метров по крутым склонам вершин - и вы попадаете в «заповедник истории», куда не ступала еще нога археолога, где, ожидая своего часа предстать перед наукой, находятся замечательные древности, подобно непрочтенной книге скрывающие свой смысл.

Наш маршрут преследовал цель - проникнуть в один из таких «заповедников». Мы долго выбирали его. Горы манят своей неизвестностью, но, честно говоря, всегда опасаешься ошибиться, выбрать не самый интересный район. И все-таки мы решились.

Дело в том, что автор этих строк и Майербек Ошаев - научный сотрудник Чечено-Ингушского научноисследовательского института - узнали, что в одном из письменных русских документов середины XVII века упоминается «Тумцойцев кабак», то есть аул Тумсой. В последующие века аул Тумса (или Тумсой), гора Тумсой-Лам хорошо известны русским где-то по соседству с рекой Аргуном. ...» Читаем в книге «Топонимия Чечни»[13]: «Тумсойн лам (Тумсойн лам) «Тумсойцев гора» - то же, что и Борзойн лам. На ю. Тумса и Борзой. В его звене имеются следующие топонимы: БІавс корта - Башни вершина, Тумсойн хьех - Тумсойцев пещера; БІачин ирзу - Бачин (л) поляна; ВахІабан ирзо - Вахаба (л) поляна; Мусхьажи ирзо - Мусхажи (л) поляна; Тумса басса - Тумса склон; Соьлечун чурт дегІа меттиг - Авариа стелла стоит где».[13, с. 204] Описание топонима «Тумсойн лам», произведенное краеведом А. Сулеймановым, требует уточнения. Трактовка автора ««Тумсойцев гора» - то же, что и Борзойн лам...» не представляется корректной, т.к. упоминаемый «барз» (борзе..., в переводе на русский язык - холм, курган, небольшая вершина) является всего лишь частью от общей природно-географической местности, составляющий весь массив горы Тумсойн лам.

Продолжим текст очерка-рассказа далее: «... Ранние русские источники были осведомлены лишь о наиболее крупных и мощных чеченских родо-племенных группах. Значит, аул Тумсой и населявшая его одноименная тайпа были немалой силы в горах. Так родилось решение обследовать окрестности аула. Бывавшему прежде в Тумсое Майербеку Ошаеву не раз доводилось слышать, что местные жители находили у селения древние могильники. 
И вот преодолены 8 километров крутого подъема по разбитой проселочной дороге, ведущей в аул. Видно, что машины не столь уж часты в этих местах. Тем приятнее исконно горская, рожденная в неведомых веках и бережно сохраняемая поныне забота о путнике: через каждые 1-2 километра пути весело журчит ледяной родничок, тщательно ухоженный и выложенный камнями. Рядом - скамейка, просто, но добротно сработанная из досок чинары, а над ней непроницаемым для жгучих лучей солнца шатром нависла крона старого дерева. Кто и когда посадил его? Чьи руки ухаживали за этим «стражем родника», превратившимся из тоненького саженца в коренастого замшелого исполина? Имена добрых людей канули в неизвестность, но шумит на ветру и дождях, переливается изумрудом в свете яркого дня необъятная крона-шатер. И не это ли лучший памятник тем, кто бескорыстно хотел облегчить путь-дорогу неизвестным ему людям?!

А дорога петляет все выше и выше, туда, где взметнулась над ватой облаков гора Тумсой-Лам. Уже далеко внизу - в залитой солнцем котловине - широко раскинулось селение Советское (в наше время этому селению вернули своё исконное название Шатой (Шуьйта) - примеч. наше - Дахо А.A.). Если прислушаться, то ветер донесет глухой шум Чанты-Аргуна, несущего свои воды в соседнем ущелье.

Удача сопутствовала нам. Впрочем, это, наверное, не удача, а закономерный результат тесной связи науки с жизнью. Первые же беседы с местными жителями, похожие более на популярные лекции о задачах и целях археологии, растопили лед отчужденности, проявляющейся еще порой в отношении горцев к археологам. Вскоре нам сообщили, что на одном из холмов, окружающих Тумсой, действительно находят иной раз древние могилы. Что ж, в горах очень часто и до сего дня кладбища устраиваются на освещенных солнцем сухих возвышенностях. Традиция, видимо, возникла давно.

В полном смысле нам повезло, когда наш небольшой раскоп сразу попал на захоронение. Под штыком лопаты гулко охнула каменная плита. Рядом с ней обнажилась еще одна, за ней - следующая. Плиты плотно пригнаны друг к другу, и под ними пустота. Вернее сказать, под ними не пустота, а обширная яма, стены которой обложены камнями. Это так называемый каменный ящик - очень распространенный на Кавказе тип гробницы. Появились такие усыпальницы еще в эпоху бронзового века и продолжали строиться до самого недавнего времени, пока не победила в горах мусульманская религия, принеся свой специфический обряд погребения. Каменный ящик - своего рода дом для покойника, ушедшего из жизни в иной мир, дом, построенный заботливыми сородичами на века. И вот мы зарисовываем и фотографируем его, а сами сгораем от любопытства, желая скорее узнать, что скрывается за его массивной «крышей».

Осторожно снимаем плиты перекрытия. Первое впечатление разочаровывающее. Неужели нас опередили и кто-то уже побывал в гробнице? Кости лежат бесформенной кучей, черепа удивленно глядят пустыми глазницами на пришельцев из неведомых им веков. Расчищаем захоронение, и постепенно картина проясняется.

Более четырехсот лет назад в этом каменном ящике был погребен еще сравнительно молодой мужчина, смелый воин, защитник своего рода, вся жизнь которого - бесконечная цепь схваток с врагами. Он еще щадил себя. Еще в ранней молодости после тяжелого ранения кости его левой руки срослись в локте и рука не сгибалась. В черепе его зияет отверстие, пробитое каким-то острым оружием. Удивительно сильным и выносливым был этот человек, потому что и после страшного ранения в голову он продолжал жить (отверстие стало уже зарастать молодой костью) и лишь спустя время скончался.

А через несколько лет, потеснив останки мужчины, рядом с ним легла женщина, его жена. Супруги вместе прошли нелегкий жизненный путь. Он защищал ее от врагов, насмерть рубился в сечах, охраняя свой домашний очаг, свое хозяйство. Она ждала его возвращения из походов, растила его детей, лечила его раны. Они были верными спутниками в жизни, и после смерти их похоронили вместе. Видимо, это была небогатая семья. Нехитрые сережки из низкопробного серебра и ожерелье из небольших сердоликовых бус и ракушек, железная поясная пряжка и ножичек - вот все, чем снабдили покойников их сородичи.

На холме, близ Тумсоя, мы вскрыли 3 каменных ящика, но их там гораздо больше. Холм этот - большое кладбище, оставленное многочисленным родом в период XIV-XVII веков. Интересно, что во всех гробницах покойники лежали обязательно головой на северо-запад. Почему? Возможно, это древний местный ритуал. Можно предположить и другое. В полукилометре к северо-западу от могильника на другом высоком холме с отвесными склонами располагается фундамент и развалины древней жилой башни - «гІала», построенной, по преданиям, основателем соседнего селения Борзой. Такие родовые или семейные жилища-крепости появляются в Чечено-Ингушетии в начале позднего средневековья. Вполне возможно, что жилая башня и могильник оставлены одним и тем же коллективом людей, похоронный обряд которого включал обязательное захоронение покойников головой по направлению к родовому очагу, к своей башне. ...»

По сведениям, полученных нами от жителей этих мест, в т.ч. и Гиреева Мовла Денильбековича, 1951 года рождения (житель с/п Борзой Шатойского района), Виноградов В.Б. здесь пишет о местности, где в указанный в тексте период (возможно и ещё ранее), находилась не одна «древняя жилая башня - «гІала», а целый башенный комплекс. Названные «холм», кладбища и остатки башенных строений располагались на восточной стороне Тумсой-лам (в сторону ущелья р. Аргун), на расстоянии около 500-600 метров от склона горы. На расстоянии около одного километра от с/п. Борзой (к юго-востоку) также имеются следы древних кладбищ, имеющие в народа название «тІекІел кешнаш», т.е. захоронения, производившиеся в своё время в несколько слоёв. 
Продолжим текст, изложенный Виноградовым В.Б в своем рассказе: «... Между прочим, и в самом ауле Тумсой, на отвесном мысе, стоит еще одна жилая башня из прекрасно обработанных и отлично пригнанных к друг другу каменных плит. ...» Здесь речь идёт о «Башне Шейх-Ваты». В одной из своих статей относительно нее мы (Дахо $\boldsymbol{A}$.A.) отмечаем следующее: «...В наше время ещё существует одна башня, именуемая как «Тумсойская башня». Это жилая башня позднего средневековья, расположенная в Шатойском районе Чечни, на левом берегу р. Тумсой-эрк. Принадлежит она тайпу Тумсой. Башня имеет высоту около 5 м. Она была построена, по всей вероятности, в XVI веке. Данная башня имеет и второе (народное) название - «Вата-шайхан г1ала» (Башня Шейх-Ваты). «Тумсойская башня» является объектом культурного наследия регионального значения».[14] Далее текст рассказа: «... По рассказам старожилов, некогда таких башен в Тумсое было более пяти. Они оберегали членов тайпа от любых неожиданностей в бурное и насыщенное бранными стычками время позднего средневековья. Приходили ли иноземные завоеватели - хищные дружины степняков, нападали ли на тайпу отряды воинственных соседей, прочные стены башен, крепкие руки и меткие глаза воинов-стрелков из луков становились защитой тумсойцев. ...» Относительно количества древних башенных строений в той же статье мы пишем: «...Число разрушенных тогда башенных комплексов тумсойцев, в имеющихся в нашем распоряжении свидетельств, варьируется. По одним сведениям их было восемь комплексов, а по другим - около тридцати (в их число относят не только жилые башни, но и сигнально-сторожевые сооружения)».[14]

Продолжаем текст рассказа: «... В одной из старинных вайнахских песен о строительстве башен поется:

Ты помни одно: убегает вода,

Камни же - остаются!

Почему же в окрестностях Тумсоя уцелела одна единственная башня? (жирным шрифтом выделено нами - Дахо А.A., Дахо Д.А.) Как погибли другие крепкостенные шедевры народного зодчества? Может быть, они рухнули после землетрясения? Или сровняли их с землей победоносные враги?

Нет, - отрицательно качают головами тумсойцы, - наши деды сами разрушили башни. (Bыделено нами Дахо А.А., Дахо Д.А.) Очень не хотелось им делать этого. С тяжкими сердцами разбирали по камню убежища, очаги своих предков. И везли их вон на тот холм в Борзое, где визгливый мулла (выделено нами - Дахо $\boldsymbol{A}$. $A$., Дахо Д.А.) руководил работами по воздвижению мечети. «К чему вам эти крепости, правоверные? (выделено нами - Дахо А.А., Дахо Д.А.) Ваше спасение и защита здесь, в мечети, у стен всемилосердного и всемилостивого аллаха». - твердил он.

И горцы, задавленные тяжкой нуждой, беспросветной нищетой, крушили древние строения, уничтожая, сами того не ведая, раз и навсегда прекрасные памятники своей истории. Так исчезли башни Тумсоя и языческие святилища (выделено нами - Дахо А.А., Дахо Д.А.) около них: камней для огромной мечети требовалось много.

О, эти вечные камни! Сначала они служили одному богу, потом - другому, третьему. Мимо них, по ним шли и шли люди и шептали молитвы и несли посильные дары в жадные лапы жрецов, мулл. (Выделено нами - Дахо А.А., Дахо Д.А.) И каждый просил о чем-то своем. Сколько горя и слез видели вы, вечные камни?!

- Нет бога, кроме аллаха... Вечная благодать снизойдет на ваш аул... - так уверяли тех, кто, отрывая время и силы от необходимых хозяйственных работ, щедро тратил их на возведение мусульманского храма. И мечеть росла на пригорке, как бы придавливая своим серым унылым телом утонувшие в зелени садов бедные горские сакли. (Выделено нами - Дахо А.А., Дахо Д.А.) Ее строили навечно...» Здесь мы вновь прервём изложение текста рассказа Виноградова В.Б. для своего комментария к изложенному материалу. Выше мы намеренно производили в тексте выделения жирным шрифтом, чтобы вернуться к ним. Автор задается вопросом - «Почему же в окрестностях Тумсоя уцелела одна единственная башня?» и далее соглашается с тем, что на этот счёт сказали «тумсойцы». (Нет, - отрицательно качают головами тумсойцы, - наши деды сами разрушили башни.) Вслед за этим, автор делает такую заключительную трактовку затронутого вопроса: «И горцы, задавленные тяжкой нуждой, беспросветной нищетой, крушили древние строения, уничтожая, сами того не ведая, раз и навсегда прекрасные памятники своей истории. Так исчезли башни Тумсоя и языческие святилища около них: камней для огромной мечети требовалось много». Конечно же, мы не согласны с такой трактовкой вопроса. Она не только не верна, на наш взгляд, но и вредна самим своим смыслом. Напомним, с XVI-го и XVII вв. н. э., с появлением в арсенале вооружения войск различных иноземных захватчиков артиллерии и других средств массового поражения, чеченцы уже прекратили строить в горах каменные башни, т.к. они перестали играть эффективную оборонительную роль, ввиду уязвимости при использовании нападавшими своей артиллерии и др. средств огневой атаки. То же самое было и относительно жилых башенных строений. Другой причиной этому послужил и начавшийся процесс переселения чеченцев с гор на равнину. В. Виноградов и В. Байбик об этом пишут так: «... В Чечне башенные поселки несколько скромнее. Это объясняется, очевидно, тем, что чеченцев раньше (по крайней мере с XVI века), чем ингушей, затронул процесс переселения с гор на плоскость».[7, с. 35] В новых условиях принцип «За каменной стеной» сменился преимуществами маневров нападения и обороны с активным использованием лесных укрытий и рельефа горной местности. И мулла, вопрошавший «К чему вам эти крепости, правоверные?», - на наш взгляд, - был совершенно прав. Но здесь дело не только в этом... Если верить изложению автора, выходит, что башни 
тумсойцев были разрушены самими тумсойцами. Если заключить корректно, то автор в этом месте выдаёт желаемое за действительное. Не только башни, но и многочисленные документальные и природные памятника чеченской истории, в том числе расположенные в районах Аргунского ущелья, были неоднократно подвергаемы жестокому уничтожению бесчисленными вражескими полчищами на протяжении многих веков. Сокрушительному уничтожению они подверглись в период нашествия армии Хромого Тимура в конце XIV в.[15] Башни безжалостно уничтожались российской царской армией в годы Кавказской войны. Одной из причин служило и то, что они (башни) могли быть убежищами для абреков и ещё тех, кого преследовало царское правительство. В.А. Авие в очерке «Поездка в Чечню» описывает следующее событие: «Кончался срок моего пребывания в Шатое, и я должен был распроститься с моими радушными хозяевами и с маленьким шатоевским обществом, с которым я успел перезнакомиться. В последний раз вышел я на балкон, чтобы окинуть еще раз взором приютивший меня живой уголок: две башни, сторожащия Цугуной, стояли прямо передо мною среди зеленого леса и скал, и взор мой невольно остановился на их стенах, когда я вспомнил вчерашний день. Как раз накануне моего отъезда крепостная рота артиллерии производила учебную стрельбу. Вывезли из крепости убогия пушки, разставили на горе по ту сторону Аргуня красные флаги и караульщиков, чтобы предупредить население об опасности попасть в сферу стрельбы. Мишенью для этой стрельбы самым варварским образом избрали две старинные башни. При первом же залпе соседния горы усеяны были народом, высыпавшим из селений и на безопасном разстоянии наблюдавшим стрельбу. Но, не к чести старых пушек, снаряды хотя и попадали в цель, но древние памятники эти, вероятно, прочно были построены: к большой радости и гордости чеченцев, башни остались невредимы и продолжали твердо стоять на своих местах. Я тоже наблюдал стрельбу и невольно подумал при этом о большой безтактности поступка распорядителя ученья, который мог бы позаботиться приготовить другия мишени для такого случая. На лицах чеченцев ясно выражалось презрение к русскому оружию, даже насмешка над несчастными пушками и злоба за неуважение к их старинным памятникам, и между ними раздавались торжествующия, злобные восклицания».[16, с. 285-286] Уничтожались башни в годы депортации чеченцев и ингушей в Казахстан и Среднюю Азию (1944 - 1957 гг.) и значительно позже, те остатки строений, которые ещё сохранялись, в годы военных событий в Чеченской Республике в 1990-х и в начале 2000-х гг. Обращают на себя внимание и некоторые формулировки и словарные выражения в данном отрывке из тексте Виноградова В.Б. К примеру, «... визгливый мулла», «... люди ... шептали молитвы и несли посильные дары в жадные лапы жрецов, мулл», «...мечеть росла на пригорке, как бы придавливая своим серым унылым телом утонувшие в зелени садов бедные горские сакли». В них отчетливо видна атеистическая нелюбовь (если не ненависть) автора ко всему мусульманскому, в частности - к вероисповеданию чеченцев. Если и не часто, но в сочинениях Виноградова В.Б. такие формулировки встречаются там, где для автора появляется удобный момент. В качестве одного из таких примеров можно назвать т.н. «...доводы науки против доводов религии» в работе «Время, горы, люди».[6, с. 17]

Продолжим изложение текста рассказа дальше: «... Но вот в горы пришла новая жизнь. Люди Чечни завоевали ее своей кровью, с оружием в руках, в борьбе с темными силами прошлого и едва ли не первую очередь в борьбе с религиозным дурманом, с реакционным мусульманским духовенством. И с годами опустела мечеть в ауле, обветшала ее крыша, сгнили массивные двери и оконные рамы. Несколько дряхлых стариков, одетых во все черное и с неизменными четками в руках, еще приходят к ее серым стенам. (То же самое, о чем писали чуть выше; выделено нами - Дахо А.А., Дахо Д.А.) Они присаживаются на корточки и ведут негромкий, медлительный разговор. Это разговор о прошлом, о настоящем.

Быстро опускаются в горах сумерки, они заполняют все уголки хмурого здания (выделено нами - Дахо A.A., Дахо Д.А.). А в нескольких десятках метров гремит музыка, слышны веселые голоса. Это сельский клуб широко распахнул свои двери тумсойцам и борзойцам. Здесь царство молодости, веселья, глубокой веры в свои силы, силы народа. Здесь пытливые расспросы приезжих лекторов, ученых. (Все выделения жирным шрифтом наши - Дахо А.А., Дахо Д.А. В этом отрывке автор довольно контрастно применяет своеобразную антитезу, пытаясь сильнее показать «неблаговидное» старое и отжившее свой век (на взгляд самого автора) и новое - «веселое», «сильное», «народное»). Здесь мы впервые услышали рассказ о том, как погибли башни Тумсоя, разрушенные в угоду новой тогда религии.

Впрочем, вернемся к этим башням, к тем временам, когда они были залогом жизни в горах. Видно, не всегда спасали тайпу прочные крепости. Когда силы врагов были слишком значительны и не было надежды устоять против них, приходилось уходить глубже в горы. Недаром живет у вайнахов мудрая поговорка: «Отступить перед неизбежным поражением - это не трусость».

А отступать приходилось тумсойцам не раз. Аргунское ущелье становилось ареной многих войн и походов. Спасение было там, высоко в горах. А в просторных долинах земля дичала и отбивалась от обессилевших человеческих рук. Зарастали стежки и тропинки, покосились и утонули в высокой крапиве и бурьяне ветхие плетни, рухнули сакли, кустарник разросся, и его ветви скрыли от глаз затянутые ряской родники. Обветшали и осыпались даже кладбищенские ограды; люди не имели возможности ухаживать за могилами своих отцов и дедов. Но жизнь не прекращалась. Ее бурные источники просто переносились на другие места. 
В двух километрах от Тумсоя, на вершине горы Ватан-Корт (выделено нами - Дахо А.А., Дахо Д.А.), мы обнаружили еще один могильник в каменных ящиках, по обряду захоронения и могильному инвентарю близкий Тумсойскому. Плоская вершина Ватан-Корта представляет собой непреступное естественное убежище. Дремучие леса покрывали раньше исключительно крутые склоны горы с севера, востока и запада, и враг едва ли мог надеяться найти заветную тропинку к вершине и воспользоваться ею. С юга склон обрывается полукилометровой пропастью, на дне которой ревет Аргун. На вершине бьет чистый родник, раскинулись прекрасные луга для пастбищ. Трудно придумать лучше место на случай необходимости укрытия. Его и облюбовали тумсойцы. Кто знает, сколько времени использовали они это убежище, но, думается, не один раз и на долгие сроки, коль на горе видны не только следы поселения, но и находится могильник. «Терпение - стан победы», - говорят чеченцы. А местные предания живо повествуют о сокрушительных нашествиях врагов, о длительной борьбе с ними тумсойцев, о трагических кровопролитных схватках, когда от всей тайпы Тумсой оставалось в живых лишь несколько человек. ...» Выделенный нами топоним «Ватан-Корт» на чеченском языке звучит как «Вати-Корт», «Ват-Корт», «Ватас корта таІийна меттиг» (Место, где Вата сделал земной поклон). В названии речь идёт о Шейх-Вате. «Вата - первый проповедник ислама в Аргунском ущелье. В народе его называют Вата-шайх. Похоронен на кладбище в с. Дуба-Юрт».[13, с. 205] «Относительно его (Вата-шайха примеч. наше - Дахо А.А.) биографических данных и жизнедеятельности существует целый ряд версий. В настоящее время мы работаем над тем, чтобы на основе более тщательного исследования, учитывая при этом все имеющиеся в нашем распоряжении материалы полевыХ записей, сформулировать свою точку зрения по всем имеющимся вопросам относительно личности Шейха-Ваты».[14]

Продолжение текста рассказа: «... Судя по обилию одновременных могильников и количеству башен, а также по тому, что огромная гора Тумсой-Лам названием своим прямо связана с именем тайпы, можно утверждать, что тумсойцы были сильной группой среди чеченских племен. Именно поэтому известия о них дошли до русских уже в раннем периоде их знакомства с Чечено-Ингушетией.

Через несколько дней мы покидали Тумсой. Постояли немного у башни, поднялись на могильный холм, перебрали в уме записанные сказания. И, повторяя путь многих и многих поколений горцев, пошли вниз к солнечной Шатоевской котловине. Сзади осталась хмурая вершина древней и много повидавшей горы тумсойцев.

Ученые, несомненно, еще не раз вернутся в этот богатый древностями и легендами район горной Чечни. Вернутся, чтобы глубоко и всесторонне изучить его, чтобы прочесть страницу за страницей всю «книгу» башен и могильников, которая зовется историей».

Подытоживая всё изложенное, можно сделать следующий вывод. Профессор Виноградов В.Б., безусловно, оставил после себя значительное творческое наследие. Он внес немалый вклад в советскую и российскую историческую науку и, в частности, заметный вклад в кавказоведение. Его труды востребованы исследователями, студентами и читателями. В них представлен огромный информативный и фактический материал, основывающийся на документах, свидетельствах и выводах, сделанных автором на результатах своего многолетнего исследовательского труда. Однако его сочинения не лишены многих недостатков, упущений, а порой и научной несостоятельности. Ввиду чего, на ряду со всем отмеченным выше, требуют к себе и критического отношения.

\section{СПИСОК ЛИТЕРАТУРЫ:}

1. С.Л. Дударев. Виталий Борисович Виноградов (страницы жизни и творчества). Научная мысль Кавказа. №1, 2013. Стр. 109-112 (с.110);

2. Халид Ошаев, «Против лженаучной эквилибристики» // журнал «Вайнах», №1, 1998 г.;

3. А.А. Журтова, А.Н. Максимчик. Историография российско-кавказских отношений в XVI-XIX в.: Два подхода к осмыслению проблемы. Владикавказ. 2017, : СОИГСИ ВНЦ РАН, 2017. - 440 с.;

4. С.Л. Дударев. Основные вехи научного творчества, педагогической и организаторской деятельности В.Б. Виноградова. Вопросы южнороссийской истории. Выпуск 18. Посвящается 50-летнему юбилею научнопедагогической Школы историка-кавказоведа В.Б. Виноградова. Под редакцией С.Н. Ктиторова. Армавир. 2013. C. 13-16;

5. Ислам Баудинов. В.Б. Виноградов, кавказоведческая Школа академика В.Б.Виноградова, история народов Северного Кавказа. 21. Апреля 2011 г. // https://ran55.livejournal.com/2781.html;

6. В.Б. Виноградов. Время, горы, люди. Книга очерков и краеведческих репортажей. Грозный, ЧеченоИнгушское книжное издательство, 1980 : - 168 с. (физ.);

7. В.Б. Виноградов, В. Байбик. О памяти, о подвигах, о славе!. Под редакцией Н.П. Гриценко. Грозный, Чечено-Ингушское книжное издательство. 1972;

8. В.Б. Виноградов. Тайны минувших времен. Москва. Издательство «Наука», 1966: - 168 с. (физ.);

9. Дахо А.А. «Март-нах»: кто они? Журнал «LINGUA-UNIVERSUM». №3, 2020. Стр. 63-69; 
10. Шавлаева Т.М., Дахо А.А., Тесаев 3.А., Берсанова 3.Х.-А. Нахча-Корта: по следам минувших столетий (результаты первого этапа историко-этнографической экспедиции). Журнал «Вопросы национальных и федеративных отношений». №9 (78). Т. 11. М., 2021. С. 2428-2438;

11. Шавлаева Т.М., Дахо А.А., Тесаев 3.А., Садулаев Э.С. К вопросу изучения Ачхоевско-Бамутской горнолесистой зоны Чеченской Республики (по материалам историко-этнографической экспедиции). Журнал «Вопросы национальных и федеративных отношений». № 10 (79). Т. 11. М., 2021. С. 2428-2438; С. 2696-27-09;

12. В. Б. Виноградов. Через хребты веков. - Грозный: Чечено-Ингушское книжное издательство, 1970. 166 c.;

13. А.С. Сулейманов. Топонимия Чечни. Грозный, ГУП «Книжное издательство», 2005. - 711 с.;

14. Дахо А.А. Краткие сведения о чеченском тайпе Тумсой // https://proza.ru/2021/03/16/866; (c) Copyright: Дахо Алви, 2021;15. Тесаев 3.А. Исторические сообщения о нашествии Тимура Барласа на Чечню (Симсим) // Таллам. 2020. № 3 (20). С. 27-39. - На чеченск. яз.;16. В.А. Авие. Поездка в Чечню.//Исторический вестник. Том СХІХ. СПб, 1910 г.; 